\title{
How old are you-Evaluation of age reading methods for the invasive round goby (Neogobius melanostomus, Pallas 1814)
}

Florin, Ann-Britt; Hüssy, Karin; Blass, M.; Oesterwind, D.; Puntila, Riikka; Ustups, D.; Albrecht, C.; Heimbrand, Y.; Knospina, E.; Koszarowski, K.

Total number of authors:

11

Published in:

Journal of Applied Ichthyology

Link to article, DOI:

10.1111/jai.13596

Publication date:

2018

Document Version

Peer reviewed version

Link back to DTU Orbit

Citation (APA):

Florin, A-B., Hüssy, K., Blass, M., Oesterwind, D., Puntila, R., Ustups, D., Albrecht, C., Heimbrand, Y., Knospina, E., Koszarowski, K., \& Odelström, A. (2018). How old are you-Evaluation of age reading methods for the invasive round goby (Neogobius melanostomus, Pallas 1814). Journal of Applied lchthyology, 34(3), 653-658. https://doi.org/10.1111/jai.13596

\section{General rights}

Copyright and moral rights for the publications made accessible in the public portal are retained by the authors and/or other copyright owners and it is a condition of accessing publications that users recognise and abide by the legal requirements associated with these rights.

- Users may download and print one copy of any publication from the public portal for the purpose of private study or research.

- You may not further distribute the material or use it for any profit-making activity or commercial gain

- You may freely distribute the URL identifying the publication in the public portal 


\title{
How old are you-Evaluation of age reading methods for the invasive round goby (Neogobius melanostomus, Pallas 1814)
}

\author{
A.-B. Florin ${ }^{1}$ (D) | K. Hüssy ${ }^{2}$ | \\ M. Blass ${ }^{1}$ \\ D. Oesterwind ${ }^{3}$ \\ R. Puntila ${ }^{4}$ \\ D. Ustups ${ }^{5}$ \\ C. Albrecht $^{3}$ | Y. Heimbrand ${ }^{1}$ \\ E. Knospina ${ }^{5}$ \\ K. Koszarowski ${ }^{6}$ \\ A. Odelström ${ }^{1}$
}

${ }^{1}$ Division of Coastal Research, Department of Aquatic Resources, Swedish University of Agricultural Sciences, Öregrund, Sweden

${ }^{2}$ National Institute of Aquatic Resources (DTU Aqua), Technical University of Denmark, Charlottenlund, Denmark

${ }^{3}$ Thünen Institute of Baltic Sea Fisheries, Rostock, Germany

${ }^{4}$ Finnish Environment Institute, Marine research centre, Helsinki, Finland

${ }^{5}$ Fish Resources Research

Department, Institute of Food Safety, Animal Health and Environment "BIOR", Riga, Latvia

${ }^{6}$ Division of Marine Biology and

Ecology, Institute of Oceanography, University of Gdańsk, Gdynia, Poland

\section{Correspondence}

A.-B. Florin, Division of Coastal Research, Department of Aquatic Resources, Swedish University of Agricultural Sciences, Öregrund, Sweden.

Email: ann-britt.florin@slu.se

Funding information

Swedish Agency for Water and Sea

Management; BONUS BIO-C3 project;

BONUS (Art 185); EU; Academy of Finland;

German Federal Ministry of Education and

Research

\section{Summary}

In the Baltic, the first observation of the round goby (Neogobius melanostomus, Pallas 1814) was made in 1990 . Within the past decade the species became invasive and spread rapidly throughout the Baltic Sea. Studies about the fishes potential impacts on resident species promote the need for an increasing knowledge of their basic stock structures such as growth rates, longevity and mortality, which all rely on accurate estimates of age. Former studies on the round goby have used several different age reading techniques. In this study, we compared three standard otolith preparation methods for ageing and present the best procedure for the invasive round goby. The results showed significant differences in age estimates of the same fish between the different preparation methods and between readers. The estimation of the first annulus, the first year, was the most problematic. The overall agreement was lowest when reading the whole otoliths while the best performance was achieved with sectioned and stained preparation method. Depending on method used the growth estimates also differed. The results question comparability between previous studies and highlight the importance of harmonised aging procedures for the round goby for obtaining correct estimates of population parameters such as growth rate, age at maturity, and longevity.

\section{1 | INTRODUCTION}

The round goby (Neogobius melanostomus, Pallas 1814) is an invasive fish currently established in many different habitats throughout most of the Baltic Sea (Kotta, Nurkse, Puntila, \& Ojaveer, 2016), major European rivers, and the Laurentian Great Lakes (Kornis, MercadoSilva, \& Vander Zanden, 2012). It originates from the Ponto-Caspian region and was likely introduced to the Baltic through the channel system with ship traffic (Sapota \& Skóra, 2005). Since it was first observed in the Gulf of Gdansk in 1990, it has spread throughout the eastern and western Baltic Sea (Azour et al., 2015) as well as to the northern parts of the Baltic, Bothnian Sea (Kotta et al., 2016). With rapid population growth and known adverse impacts on the native biota (reviewed in Kornis et al., 2012), the population characteristics of the round goby in the Baltic Sea have attained increasing interest.

In order to assess important population characteristics of the species, such as growth rate, age at maturity, mortality, and life span, accurate age reading is necessary. Age is traditionally determined by counting seasonally recurring growth zones in the fish's otoliths (Secor, Dean, \& Campana, 1995). In temperate latitude these growth zones are normally related to seasonally varying environmental temperature and prey availability (Beckman \& Wilson, 1995).

The first studies of round goby biology were based on age estimates using various different otolith preparation methods (Azour et al., 2015; Maclnnis \& Corkum, 2000; Sokołowska \& Fey, 2011). Unfortunately, none of these studies showed images of round goby 
otoliths to document the visual contrast between growth zones. However, considerable overlap in size between age groups as well as discrepancies in age composition between studies suggest problems with the age estimates they were based on. Different otolith preparation and viewing methods are known to affect both precision (degree to which age readers agree) and accuracy (closeness of age estimate to true age) of age estimates (Appelberg et al., 2005; Campana, 2001; Panfili, De Pontual, Troadec, \& Wright, 2002). Traditionally ageing of fish have been done examining the sagittal otolith whole (Campana, 2001) or using a burn and brake method (Christensen, 1964) but in recent years also section and stain technique has been used increasingly (Easey \& Millner, 2008). Comparative studies between otolith preparation methods suggest that there are inconsistencies between them. First, the rings appearing in the burning process may not correspond to protein bands that are related to slower growth in the cold months and second, determining the exact optimal burn time is difficult and often results in unreadable otoliths (ICES, 2007; VanderKooy, 2009). Identification of seasonal growth zones in whole otoliths is often very difficult, and especially in older specimens subject to extensive inaccuracy (ICES, 2007; VanderKooy, 2009). A comparison between preparation methods is therefore mandatory for the development of ageing protocols of any species according to ICES procedures (Appelberg et al., 2005; ICES, 2013).

Therefore the objectives of the present study were to provide guidelines for best-practice otolith preparation methods for the round goby in order to ensure high precision in age estimates and harmonization of age determination in the future to allow comparisons within the Baltic Sea and elsewhere in their distribution range. To do so we (i) compared the results of three different otolith preparation methods - whole, burned and broken or section and stain respectively, (ii) assessed the precision of different age readers and (iii) established growth curves.

\section{2 | MATERIALS AND METHODS}

Sagittal otoliths were sampled in autumn 2014 from 104 round gobies obtained from two areas in Sweden, Karlskrona archipelago in the southern Baltic Sea ( $n=52 ; L_{T}=146 \pm 16 \mathrm{~mm}$, range 117-186 mm) and Gothenburg harbour in Kattegat $\left(n=52, L_{T}=131 \pm 24 \mathrm{~mm}\right.$, range 74-179 $\mathrm{mm}$ ). The individuals were provided by a professional fisher in Karlskrona and the Sports fishers organisation in Gothenburg. First, one whole otolith of each fish was placed in water and photographed with reflected light. Second, the otolith was processed with either burn and break ( $\mathrm{b} \& \mathrm{~b}$ ) or section and stain (s \& s) method, and photographed again. Third, the remaining otolith from the same individual was assigned to the alternate method and photographed after preparation. This approach is valid since there are no systematic differences between right and left otolith in round goby (Gümüş \& Kurt, 2009). All otoliths from the three different methods were photographed with a Leica camera DFC290 mounted on a dissection microscope Leica M205c using software LAS V4.5. All images where saved in jpeg format and 20-40x magnification was used to get an optimized picture fitting the whole otolith in image. For the $b \& b$ method the otoliths were burned over an ethanol flame, broken and placed in clay in a container with water. The transversal surface of the otolith was often very rough and in order to get good quality pictures, every otolith was photographed with reflected light. Six pictures of every otolith were stacked together using a MultiFocus function, Leica software LAS V4.5 to obtain one composite image with full focus over the whole transversal surface of the otolith. For the $s \& s$ method, otoliths were embedded in black polyester resin, sectioned $(0.4 \mathrm{~mm})$ with a variablespeed precision cutting machine Struers Accutom 50 and stained by etching the slices for $40 \mathrm{~s}$ in $1 \%$ hydrochloride acid and stained for $10 \mathrm{~min}$ in neutral red solution. The transversal sections of the otoliths were then photographed with transmitted light as described above.

Images of three otolith treatments were created for each individual fish: whole, $\mathrm{b} \& \mathrm{~b}$ and $\mathrm{s} \& \mathrm{~s}$. Image sequences were randomized within each treatment so that the identity of individual otoliths were unknown to the readers. The age of the fish was determined for each image by nine different readers from five countries from the Baltic Sea area. All readers were experienced in age determination of fish but with limited or no experience in aging of round goby. For the study, age readers were not allowed to discuss their results across the group and were therefore independent. Some readers were not able to estimate the age for all individuals, resulting in between 281 and 305 otolith images assessed per reader.

Data on estimated age were analysed based on traditional procedures using modal age (most frequent age), average agreement $\left(n_{\text {modal age }} / n_{\text {total }} \times 100\right)$ and coefficient of variation as well as bias plots and -tests (Eltink, Newton, Morgado, Santamaria, \& Modin, 2000). Age reading bias and reader comparisons of preparation method effects were tested using Friedman rank sum test and post-hoc Wilcoxon signed rank test for multiple comparisons using $R$ ( $R$ Development Core Team, 2009).

\section{3 | RESULTS}

Otolith preparation strongly influenced the numbers of rings visible on the otoliths (Figure 1.) Overall agreement was lowest and variance (CV) highest in whole otoliths $(45.7 \pm 9.9 \%$ and $31.1 \pm 8.3 \%)$ followed by $b \&$ b otoliths ( $58.7 \pm 10.1 \%$ and $22.4 \pm 8.6 \%$ ). The best performance was achieved in the $s \& s$ otoliths $(71.3 \pm 8.6 \%$ and $21.5 \pm 9.9 \%)$

The age-bias-plots revealed that whole otolith method performed poorly since the variations in the modal age are not consistent even in single readers (i.e., 1 year older over all ages, leading to a line parallel with the 1:1 modal age line). The age-bias plots of both $b \& b$ and $s$ $\& s$ methods resulted in a linear relationship between read age and modal age. Two readers consistently aged fish 1 year older and one reader consistently aged older individuals much younger than all other readers. Uncertainties were highest in the oldest and youngest individuals, exemplified with the $s \& s$ method bias plots (Figure 2). Bias tests showed that only three readers agreed with each other across all three methods (Table 1). 


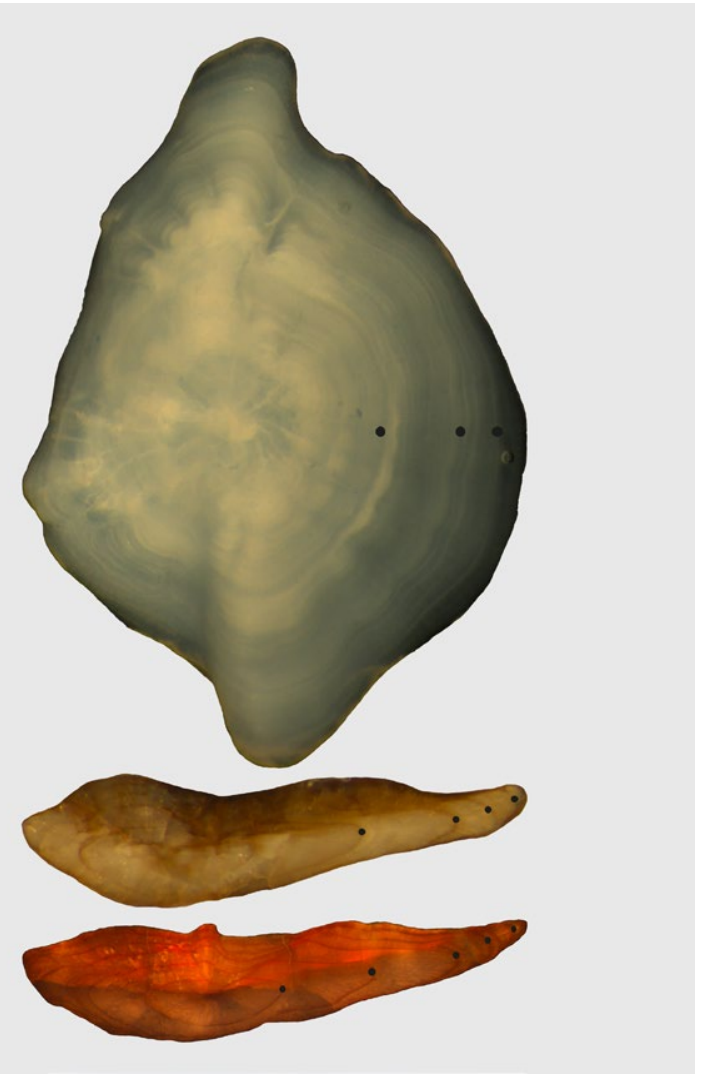

FIGURE 1 Pictures of otoliths from the same fish treated by three different methods, whole, burn \& break and section \& stain

The within-reader comparison of preparation methods gave unclear results since not all readers showed bias in the same method. Most readers scored highest average ages in the whole otolith method with similar ages in b \& b and $\mathrm{s} \& \mathrm{~s}$ (Table 2). Consequently, comparing modal ages of the same individual between methods revealed highest agreement between $\mathrm{s} \& \mathrm{~s}$ and $\mathrm{b} \& \mathrm{~b}$ method (Spearman Rho $=0.83, p<.001, / n=97$ ) and lower agreement between the other methods (whole-s \& s: Rho=0.61, $p<.001, n=97$; whole-b \& b: Rho = 0.48, $p<.001, n=104$ ). Generally fish aged using the $b \& b$ method were estimated to be younger compared to the other methods (compared to whole: $Z=-2.7$, $n=104, p<.01$; compared to s \& s: $Z=-2.6, n=97, p<.01)$.

The size-at- $t$ modal age plots for the three different methods revealed that using whole otoliths leads to underestimation of the size at age for older individuals ( $>3$ years) compared to the other methods (Figure 3).

The combined results of analyses of agreement between readers for each method separately, inter-reader bias and comparison of method performance within single readers, document that the section and stain method results in the highest precision in ageing of the round goby.

\section{4 | DISCUSSION}

Accurate age determination is a prerequisite for estimation of basic population parameters and the current state of the population of the invasive round goby. This study has shown that different otolith preparation methods used for round goby aging resulted in considerable differences in age estimates and demonstrates the need of a harmonized age reading protocol (Appelberg et al., 2005; ICES, 2013). Some of the preparations tested here are fast and inexpensive - and hence widely used. However, the best performing method (sectioned and stained) is not among them. Being a non-commercial, relatively new species in many areas, not only experienced age readers are interested in the age of round goby, which highlights the need for an accurate method of aging this species. The method using sectioned and stained otoliths resulted in the highest agreement and lowest variance as well as the highest number of readers without bias in relation to each other. Therefore, we suggest that this method should be used as the primary method for age reading of the round goby to allow comparisons across populations. This technique has previously proven more accurate and reliable than traditional whole-otolith based methods (Easey \& Millner, 2008) including other Baltic Sea species such as flounder (Platichthys flesus, Linnaeus 1758) (ICES, 2007) and herring (Clupea harengus, Linnaeus 1758) (Peltonen, 2002).

However, the results also reveal that even with the best method readers did not reach the suggested $80 \%$ agreement level (Eltink et al., 2000) and had a variance far above the lower limit of $5 \%$ for a stock without age reading problems (Campana, 2001). This indicates significant reader related bias and highlights the need for calibration exercises among readers in order to standardise age reading practices. Two of the commercially most important fish species in the Baltic Sea, flounder and cod, (Gadus morhua Linnaeus 1758) suffer from problems with the quality of age readings (Hüssy et al., 2016; ICES, 2014), suggesting that age determination of demersal fish in the Baltic Sea might be especially problematic.

Age reading imprecision is generally associated with the interpretation of the first winter ring and/or the seasonality in the formation subsequent growth zones (Campana, 2001). Round goby are no exception to this, as the majority of the variation in age readings in this study arose from disagreement on the first winter ring formation. Since round goby have a prolonged spawning season, April through to September (Kornis et al., 2012), the distance of the first winter ring to the core may vary considerably between individuals depending on when they had hatched. This may result in difficulties in discriminating between the juvenile settlement ring and first true winter ring (Rehberg-Haas, Hammer, Hillgruber, Hüssy, \& Temming, 2012). Also the preparation technique in itself may contribute to this problem, in that the first winter ring may get progressively obscured as the fish gets older and the otolith bigger (Ross \& Hüssy, 2013). The seasonality of subsequent winter rings on the other hand seems to be less problematic in round goby in that the age-bias plots for all readers except one showed a linear relationship with modal age. A result which has previously been confirmed by marginal increment analysis (Sokołowska \& Fey, 2011). It is also important to note that in this study the true age of the fish is unknown but assumed to be the same as the modal age when calculating precision. Future studies should therefore include validation of the first winter ring formation in juveniles, more knowledge of areaspecific growth seasons, and ideally samples of fish with known age. 

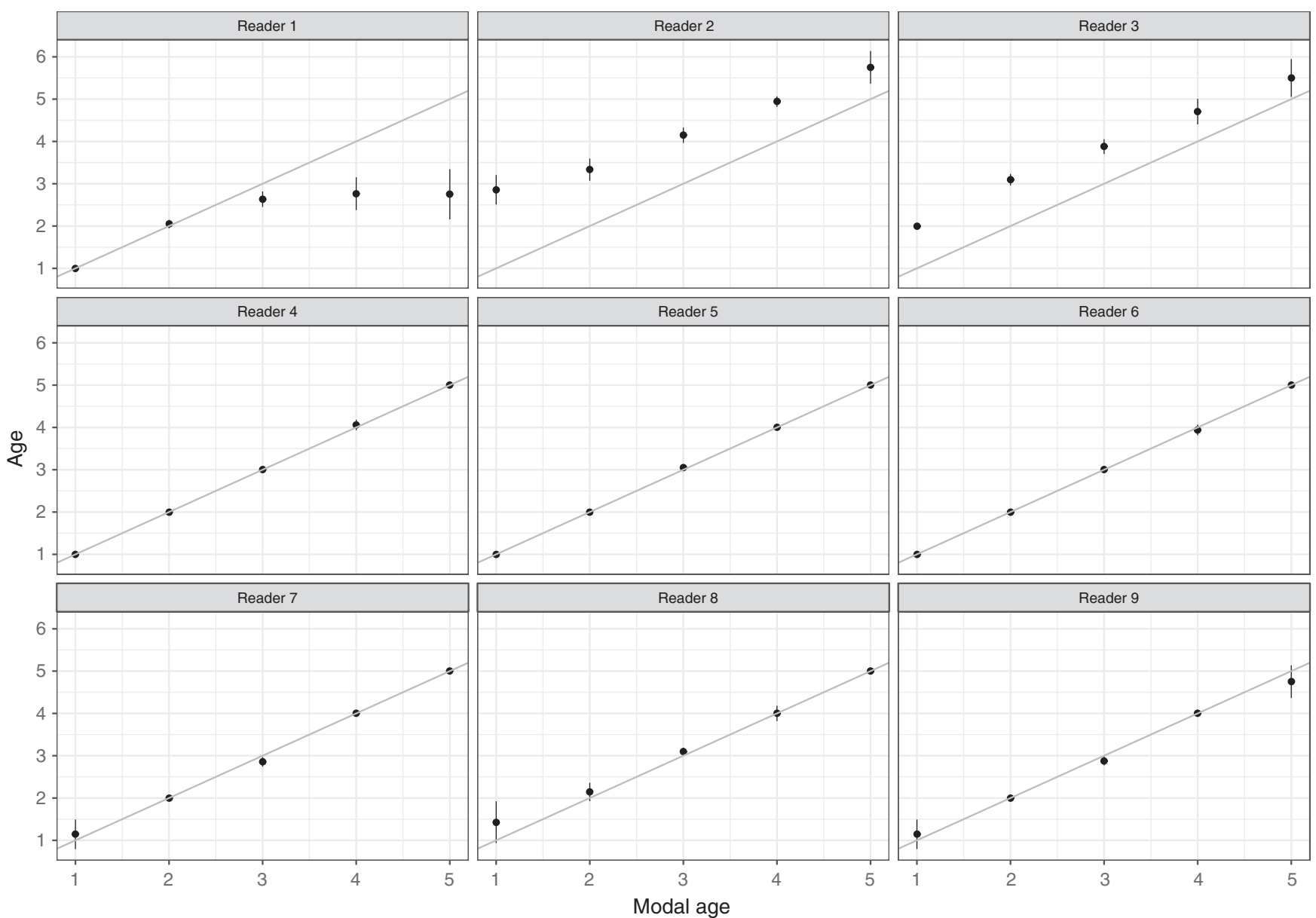

FIGURE 2 Age bias plots for the sectioned and stained otoliths for the nine different readers. Error bars show SD

TABLE 1 Inter reader bias test for ageing of sectioned and stained otoliths of round goby

\begin{tabular}{|c|c|c|c|c|c|c|c|c|c|}
\hline & Reader 1 & Reader 2 & Reader 3 & Reader 4 & Reader 5 & Reader 6 & Reader 7 & Reader 8 & Reader 9 \\
\hline Reader 1 & & $* *$ & $* *$ & $* *$ & $* *$ & ** & $* *$ & $* *$ & $* *$ \\
\hline Reader 2 & & & $* *$ & $* *$ & $* *$ & $* *$ & $* *$ & $* *$ & $* *$ \\
\hline Reader 4 & & & & & - & - & * & $*$ & * \\
\hline Reader 5 & & & & & & - & $*$ & $*$ & * \\
\hline Reader 7 & & & & & & & & $* *$ & - \\
\hline Reader 8 & & & & & & & & & $* *$ \\
\hline Reader 9 & & & & & & & & & \\
\hline
\end{tabular}

- indicates no bias $p>.05$.

${ }^{*}$ possibility of bias $.05<p>.01$.

${ }^{* *}$ certainty of bias $p<.01$.

Throughout the round goby literature, different growth rates and age distributions have been reported. Kornis et al. (2012) proposed that environmental salinity may be the primary driver for growth and longevity. However, considering that these estimates were based on different age reading methods, it is worth examining to what extent the methods used could have biased the age estimates. Maximum ages obtained from whole otoliths range between 5 and 7 years (Azour et al., 2015; Gümüş \& Kurt, 2009; Sokołowska \& Fey, 2011), 3 years for whole otoliths soaked in glycerol (Shemonaev \& Kirilenko, 2009), 3 years for frontal sectioning (Maclnnis \& Corkum, 2000) and 2 - 4 years for scales (Johnson, Bunnell, \& Knight, 2005; Simonovic, Paunović, \& Popović, 2001). Reporting differences in age and growth 
TABLE 2 Comparison within readers of ageing results of round goby using different otolith preparation methods (whole, burned \& broken (b\&b) and sectioned \& stained (s\&s)) for $\mathrm{n}$ number of fish
FIGURE 3 Total length of fish in mm plotted against modal age from the three different methods; whole - light grey, burn and break - dark grey, section and stain black line. Error bars show SD

\begin{tabular}{llcllllll} 
Mean modal age & \multicolumn{7}{c}{ Significance } \\
\hline Reader & $n$ & whole & b\&b & s\&s & Whole - b\&b & whole - s\&s & s\&s-b\&b \\
\hline Reader 1 & 97 & 2.7 & 2.54 & 2.41 & ns & $* * *$ & ns \\
\hline Reader 2 & 79 & 4.94 & 3.76 & 4.18 & $* * *$ & $* * *$ & $* * *$ \\
\hline Reader 3 & 97 & 3.62 & 3.55 & 3.88 & $\mathrm{~ns}$ & $*$ & $* * *$ \\
\hline Reader 4 & 97 & 3.01 & 2.81 & 3.02 & $\mathrm{~ns}$ & $\mathrm{~ns}$ & $* *$ \\
\hline Reader 5 & 97 & 2.91 & 2.84 & 3.03 & $\mathrm{~ns}$ & $\mathrm{~ns}$ & $* * *$ \\
\hline Reader 6 & 97 & 3.11 & 2.69 & 2.99 & $* * *$ & $\mathrm{~ns}$ & $* * *$ \\
\hline Reader 7 & 75 & 2.45 & 2.52 & 2.92 & $\mathrm{~ns}$ & $* * *$ & $* * *$ \\
\hline Reader 8 & 97 & 3.42 & 3.10 & 3.12 & $* *$ & $* *$ & $\mathrm{~ns}$ \\
\hline Reader 9 & 92 & 4.23 & 3.59 & 2.97 & $* * *$ & $* * *$ & $* * *$ \\
\hline
\end{tabular}

$\mathrm{ns}=$ non significant.

${ }^{*} p<.05$.

${ }^{* *} p<.01$.

${ }^{* * *} p<.001$

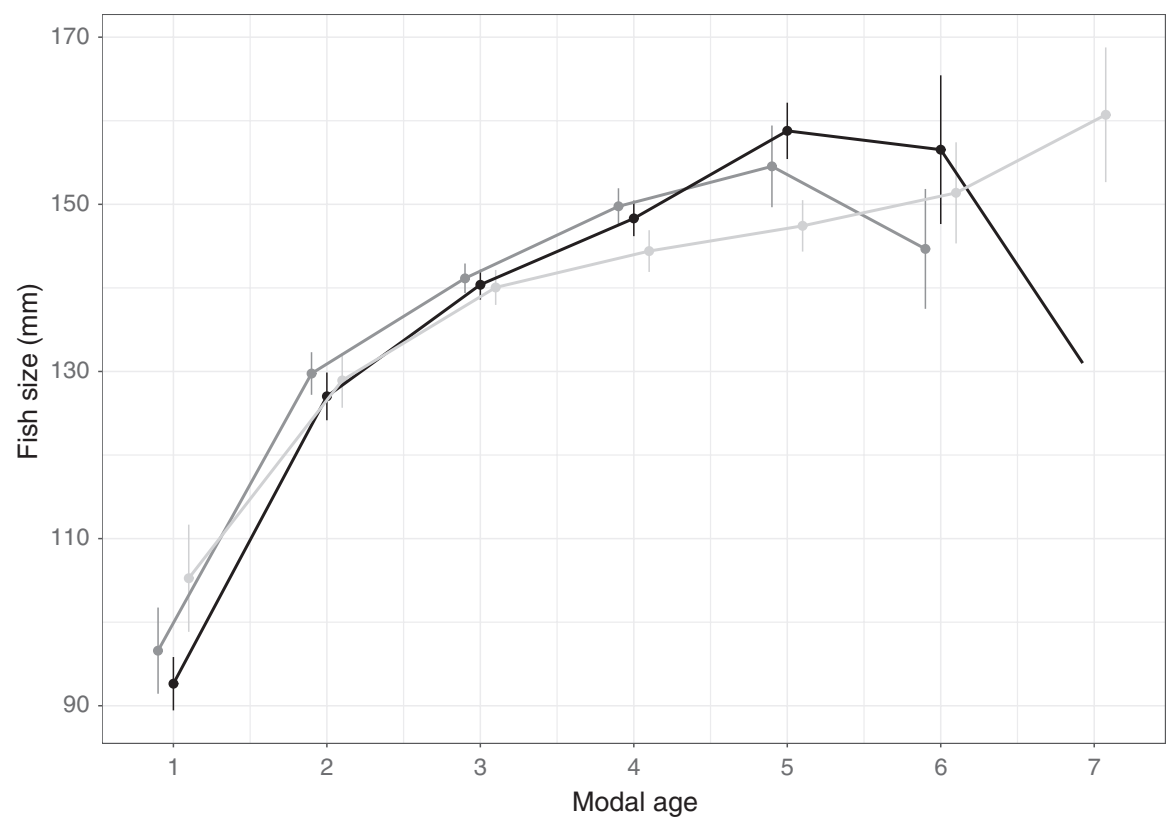

between the Black Sea and Baltic (Azour et al., 2015; Gümüș \& Kurt, 2009; Sokołowska \& Fey, 2011) and the Laurentian Lakes (Johnson et al., 2005; MacInnis \& Corkum, 2000) were unfortunately also based on different age reading methods preventing a sound assessment of whether the observed differences are unbiased. These potential impact of method on the interpretation of fundamental biological parameters of round goby further underline the need for a standardised age reading method.

\section{ACKNOWLEDGEMENTS}

The study was financed by the Swedish Agency for Water and Sea Management. Participation of Riikka Puntila and Daniel Oesterwind was partially financed by the BONUS BIO-C3 project and has received funding from BONUS (Art 185), funded jointly by the EU and the Academy of Finland and German Federal Ministry of Education and Research.

\section{ORCID}

A.-B. Florin (iD http://orcid.org/0000-0002-7531-2231

\section{REFERENCES}

Appelberg, M., Formigo, N., Geffen, A. J., Hammer, C., McCurdy, W., Modin, J., ... Wright, P. (2005). A cooperative effort to exchange age reading experience and protocols between European fish institutes. Fisheries Research, 76, 167-173. https://doi.org/10.1016/j.fishres.2005. 06.001

Azour, F., van Deurs, M., Behrens, J., Carl, H., Hüssy, K., Greisen, K., ... Møller, P. R. (2015). Invasion rate and population characteristics of the round goby Neogobius melanostomus: Effects of density and invasion history. Aquatic Biology, 24, 41-52. https://doi.org/10.3354/ab00634

Beckman, D., \& Wilson, C. A. (1995). Seasonal timing of opaque zone formation in fish otoliths. In D. H. Secor, J. M. Dean \& S. E. Campana (Eds.), Recent Developments in Fish Otolith Research (pp. 27-44). Columbia, SC, University of South Carolina Press. 
Campana, S. E. (2001). Accuracy, precision and quality control in age determination, including a review of the use and abuse of age validation methods. Journal of Fish Biology, 59, 197-242. https://doi. org/10.1111/j.1095-8649.2001.tb00127.x

Christensen, J. M. (1964). Burning of otoliths a technique for age determination of soles and other fish. ICES Journal of Marine Science, 29, 73-81. https://doi.org/10.1093/icesjms/29.1.73

Easey, M. W., \& Millner, R. S. (2008). Improved methods for the preparation and staining of thin sections of fish otoliths for age determination. Scientific Series Technical Reports, Cefas Lowestoft, 143,12 pp.

Eltink, A. T. G. W., Newton, A. W., Morgado, C., Santamaria, M. T. G., \& Modin, J. (2000). Guidelines and tools for age reading comparisons. EFAN Report, 3, 1-75.

Gümüş, A., \& Kurt, A. (2009). Age structure and growth by otolith interpretation of Neogobius melanostomus (Gobiidae) from Southern Black Sea. Cybium, 33(1), 29-37.

Hüssy, K., Radtke, K., Plikshs, M., Oeberst, R., Baranova, T., Krumme, U., ... Mosegaard, H. (2016). Challenging ICES age estimation protocols: Lessons learned from the eastern Baltic cod stock. ICES Journal of Marine Science, 73, 2138-2149. Oxford University Press. https://academic.oup.com/icesjms/article-lookup/doi/10.1093/icesjms/fsw107 (Accessed 14 March 2017). https://doi.org/10.1093/icesjms/fsw107

ICES. (2007). Report of the Workshop on Age Reading of Flounder (WKARFLO). 20-23 March 2007, Öregrund, Sweden. ICES CM, 2007/ ACFM: 10, 1-67.

ICES. (2013). Report of the Second Workshop of National Age Readings Coordinators (WKNARC2), 13-17 May 2013, Horta, Azores. ICES CM, 2013/ACOM:52. 65 pp. http://ices.dk/sites/pub/Publication\%20 Reports/Expert\%20Group\%20Report/acom/2013/WKNARC\%20 2\%202013.pdf

ICES. (2014). Report of the Benchmark Workshop on Baltic Flatfish Stocks (WKBALFLAT), 27-31 January 2014, Copenhagen, Denmark. ICES CM, 2014/ACOM:39. 320 pp.

Johnson, T. B., Bunnell, D. B., \& Knight, C. T. (2005). A potential new energy pathway in Central Lake Erie: The round goby connection. Journal of Great Lakes Research, 31(Suppl. 2), 238-225. https://doi.org/10.1016/ S0380-1330(05)70317-8

Kornis, M. S., Mercado-Silva, N., \& Vander Zanden, M. J. (2012). Twenty years of invasion: A review of round goby Neogobius melanostomus biology, spread and ecological implications. Journal of Fish Biology, 80, 235-285. https://doi.org/10.1111/j.1095-8649.2011.03157.x

Kotta, J., Nurkse, K., Puntila, R., \& Ojaveer, H. (2016). Shipping and natural environmental conditions determine the distribution of the invasive non-indigenous round goby Neogobius melanostomus in a regional sea. Estuarine, Coastal and Shelf Science, 169, 15-24. https://doi. org/10.1016/j.ecss.2015.11.029

Maclnnis, A. J., \& Corkum, L. D. (2000). Fecundity and reproductive season of the round goby Neogobius melanostomus in the upper Detroit River.
Transactions of the American Fisheries Society, 129, 136-144. https://doi. org/10.1577/1548-8659(2000)129\&lt;0136:FARSOT\&gt;2.0.CO;2

Panfili, J., De Pontual, H., Troadec, H., \& Wright, P. J. (eds). (2002). Manual of fish sclerochronology (pp. 464). Brest, France: Ifremer-IRD coedition.

Peltonen, H. (2002). Age determination of Baltic herring from whole otoliths and from neutral red stained otolith cross sections. ICES Journal of Marine Science, 59, 323-332. https://doi.org/10.1006/jmsc.2001.1156

R Development Core Team. (2009). R: A language and environment for statistical computing. Vienna: R Foundation for Statistical Computing. http:// www.R-project.org (last accessed 01 September 2015).

Rehberg-Haas, S., Hammer, C., Hillgruber, N., Hüssy, K., \& Temming, A. (2012). Otolith microstructure analysis to resolve seasonal patterns of hatching and settlement in western Baltic cod. ICES Journal of Marine Science, 69, 1347-1356. https://doi.org/10.1093/icesjms/fss112

Ross, S. D., \& Hüssy, K. (2013). A reliable method for ageing of whiting (Merlangius merlangus) for use in stock assessment and management. Journal of Applied. Ichthyology, 29, 825-832. https://doi.org/10.1111/ jai.12204

Sapota, M. R., \& Skóra, K. E. (2005). Spread of alien (non-indigenous) fish species Neogobius melanostomus in the Gulkf of Gdansk (south Baltic). Biological Invasions, 7, 157-164. https://doi.org/10.1007/ s10530-004-9035-0

Secor, D. H., Dean, J. M., \& Campana, S. E. (1995). Recent Developments in Fish Otolith Research. Columbia: University of South Carolina Press.

Shemonaev, E. V., \& Kirilenko, E. V. (2009). Some Features of Biology of the Round Goby Neogobius melanostomus (Perciformes, Gobiidae) in Waters of Kuibyshev Reservoir. Journal of Ichthyology, 49(6), 454-459. https://doi.org/10.1134/S0032945209060046

Simonovic, P., Paunović, M., \& Popović, S. (2001). Morphology, feeding, and reproduction of the round goby, Neogobius melanostomus (Pallas), in the Danube River Basin, Yugoslavia. Journal of Great Lakes Research, 27(3), 281-289. https://doi.org/10.1016/S0380-1330(01)70643-0

Sokotowska, E., \& Fey, D. P. (2011). Age and growth of the round goby Neogobius melanostomus in the Gulf of Gdańsk several years after invasion. Is the Baltic Sea a new Promised Land? Journal of Fish Biology, 78, 1993-2009. https://doi.org/10.1111/j.1095-8649.2011.02986.x

VanderKooy, S. (ed). (2009). A Practical Handbook for Determining the Ages of Gulf of Mexico Fishes (pp. 157), 2nd edn. Oceans springs: Gulf States Marine Fisheries CommissionPublication Number 167.

How to cite this article: Florin A-B, Hüssy K, Blass M, et al. How old are you-Evaluation of age reading methods for the invasive round goby (Neogobius melanostomus, Pallas 1814). J Appl Ichthyol. 2017;00:1-6. https://doi.org/10.1111/jai.13596 